\begin{tabular}{|l|l|l||}
\hline \multicolumn{2}{|c|}{ PublisherInfo } \\
\hline \hline PublisherName & $:$ & BioMed Central \\
\hline \hline PublisherLocation & $:$ & London \\
\hline \hline PublisherImprintName & $:$ & BioMed Central \\
\hline \hline
\end{tabular}

\title{
Articles selected by Faculty of 1000: proteomics of sumoylation; single-molecule sequencing; membrane glycoproteomics; MHC haplotype sequencing; transcriptome evolution
}

\begin{tabular}{||l|l|l||}
\hline \multicolumn{2}{|c||}{ ArticleInfo } \\
\hline \hline ArticleID & $:$ & 3492 \\
\hline \hline ArticleDOI & $:$ & $10.1186 /$ gb-2004-5-8-340 \\
\hline \hline ArticleCitationID & $:$ & 340 \\
\hline \hline ArticleSequenceNumber & $:$ & 21 \\
\hline \hline ArticleCategory & $:$ & Paper report \\
\hline \hline ArticleFirstPage & $:$ & 1 \\
\hline \hline ArticleLastPage & $:$ & 3 \\
\hline \hline & $:$ & RegistrationDate : 2004-7-9 \\
ArticleHistory & $:$ & OnlineDate $\quad$ 2004-7-9 \\
\hline \hline ArticleCopyright & $:$ & BioMed Central Ltd2004 \\
\hline \hline
\end{tabular}




\begin{tabular}{|l||l|l|}
\hline ArticleGrants & $:$ & \\
\hline \hline ArticleContext & $:$ & 130595588 \\
\hline
\end{tabular}

\section{Proteomics of sumoylation}

A selection of evaluations from Faculty of $\mathbf{1 0 0 0}$ covering the proteomics of sumoylation; sequencing single-molecules; membrane glycoproteomics; MHC haplotype sequencing; transcriptome evolution.

Global analyses of sumoylated proteins in Saccharomyces cerevisiae : induction of protein sumoylation by cellular stresses. Zhou W, Ryan JJ, Zhou H. J Biol Chem 2004, May 27.

For the Faculty of 1000 evaluation of this article please see: http://genomebiology.com/reports/F1000/ gb-2004-5-8-340.asp\#Zhou

\section{Single-molecule sequencing}

DNA mapping using microfluidic stretching and single-molecule detection of fluorescent sitespecific tags. Chan EY, Goncalves NM, Haeusler RA, Hatch AJ, Larson JW, Maletta AM, Yantz GR, Carstea ED, Fuchs M, Wong GG, et al. Genome Res 2004, 14:1137-1146.

For the Faculty of 1000 evaluation of this article please see: http://genomebiology.com/reports/F1000/ gb-2004-5-8-340.asp\#Chan

\section{Membrane glycoproteomics}

Lectin affinity as an approach to the proteomic analysis of membrane glycoproteins. Ghosh $\mathrm{D}$, Krokhin O, Antonovici M, Ens W, Standing KG, Beavis RC, Wilkins JA. J Proteome Res 2004, Jun 9:Articles ASAP.

For the Faculty of 1000 evaluation of this article please see: http://genomebiology.com/reports/F1000/ gb-2004-5-8-340.asp\#Ghosh

\section{MHC haplotype sequencing}


Complete MHC haplotype sequencing for common disease gene mapping. Stewart CA, Horton R, Allcock RJ, Ashurst JL, Atrazhev AM, Coggill P, Dunham I, Forbes S, Halls K, Howson JM, et al. Genome Res 2004, 14:1176-1187.

For the Faculty of 1000 evaluation of this article please see: http://genomebiology.com/reports/F1000/ gb-2004-5-8-340.asp\#Stewart

\section{Transcriptome evolution}

A neutral model of transcriptome evolution. Khaitovich P, Weiss G, Lachmann M, Hellmann I, Enard W, Muetzel B, Wirkner U, Ansorge W, Pääbo S. PLoS Biol 2004, 2:E132.

For the Faculty of 1000 evaluation of this article please see: http://genomebiology.com/reports/F1000/ gb-2004-5-8-340.asp\#Khaitovich 